\title{
Gravity Among Central Bank Balance Sheets: Monetary Policy Spill-Over on FX Volatility
}

\author{
Gábor Dávid Kiss** and Mercédesz Mészáros* \\ *University of Szeged, Faculty of Economics and Business \\ Administration, Hungary
}

Submitted: July 9, 2019 • Accepted: December 12, 2019

\begin{abstract}
Following the subprime crisis, most of the European central banks implemented several unconventional monetary instruments. As a result of the late quantitative easing, there was a shift from stimulating lending to the immediate stimulation of the securities market in the monetary policy of the European Central Bank (ECB) and of the smaller central banks, too. These securities purchase programs, first and second-market transactions, and asset purchases have led to an increase in the stock of securities held by the central banks, whose spill-over effects have not been fully explored yet. The aim of our research is to identify the spillover effects of the central banks' unconventional instruments and quantitative easing on currency volatility while considering the relative size of the issuing central bank and the situation of small open economies. By running an adapted version of gravity models, we analyzed a sample of six European central banks and the ECB. Based on our results, the high volatility levels of European currencies around the eurozone have come from their relative smallness and unconventional monetary policy, and considerations about safe havens have a reducing power on $F X$ volatility.
\end{abstract}

JEL classification: E52, E58, E43, C33

Keywords: interest rate parity; unconventional monetary policy; panel regression.

${ }^{*}$ Corresponding Author. E-mail: kiss.gabor.david@eco.u-szeged.hu The article is processed as an output of a research project, New National Excellence Program, registered by the Hungarian Government's EMMI under the registration number UNKP-18-2. 


\section{Introduction}

As a result of the global financial crisis and the eurozone sovereign debt crisis, monetary policy has undergone a big instrumental and structural change during the past ten years. After 2008, major central banks, including the U.S. Federal Reserve (Fed) and European Central Bank (ECB), exhausted the possibilities of easing traditional interest rates. Therefore, they engaged in large-scale asset purchases (LSAP), such as sovereign bonds. The aim of this policy was to solve the problems caused by the crisis: to fight against deflation and restore financial stability. In addition, with the emergence of unconventional instruments, it has become even more important to monitor the spill-over effects of the monetary policy of central banks, which can then precipitate any chain of the monetary transmission mechanism (e.g., foreign exchange rates, inflation, and asset prices). For example, with turbulent capital flowing through the exchange rate channel, some currencies (CZK, CHF) appreciated excessively, whereas others (HUF) depreciated dramatically in the past ten years. The European Central Bank showed a deeper commitment towards quantitative easing $(\mathrm{QE})$, but the "stickiness" of the unconventional relief manifested in the continuation of loose monetary policy such as reinvesting the maturing bonds after the beginning of 2019, as Draghi (2019) mentioned in his speech. The example was followed by several central banks of small open economies, such as the recently announced corporate bond purchase (NKP) program of the Hungarian National Bank, which produced significant cross-country effects.

Monetary autonomy can be defined as a degree of freedom, for example, how the central bank is capable of focusing on the domestic macroeconomic conditions, what can be distorted by global capital spill-overs, key central bank decisions, and changes of investors' sentiment (Bank of International Settlements, 2011; Plümper and Troeger, 2008). Currency valuation under free-floating regimes depends on the same factors as the indirect interventions of the monetary policy, which will be mirrored in the volatility of this asset.

The main objective of our research is to identify the impact of relative size differences among the European Central Bank and the non-euro user central banks $\}^{1}$ (with relatively small open economies) around it, with a special focus on QE programs, to see their impact on $F X$ volatility. The adaptation of the gravity model helps to extend the mainstream interest rate parity with the structural changes of the central bank balance sheet (mainly due to the application of some unconventional monetary instruments) and macro-variables, which can be relevant for the transmission mechanism. Activities related to unconventional instruments have their footprint on central bank balance sheets, as the theoretical background section will present. However, the following question should be answered: is QE for everyone, or for small and open economies the implementation of such measures would have turbulent impacts on currency volatility? .

\footnotetext{
${ }^{1}$ Czech National Bank (CNB), Danish National Bank (DNB), Hungarian National Bank (MNB), Polish National Bank (PNB), Swiss National Bank (SNB) and Sweriges Riksbank (SR)
} 
QE measures were initially introduced as a temporary agenda, but they have now been operational for nearly a decade with increasing popularity. The main contribution of this paper is that it tests the adaptability of the gravity model setup on this topic, and it employs the structural changes of the central bank balance sheet in one variable. This paper considers the entire, eleven-year-long quarterly dataset to cover the different stages of the crisis and post-crisis period (from 2007 Q1 to 2018 Q1). The examined sample covers the ECB and European non-eurozone member central banks that used unconventional instruments during the period under review (after the crisis), such as Czechia, Denmark, Hungary, Poland, Sweden, and Switzerland. Overall, our results support the idea that currencies around the eurozone have a naturally high volatility due to their relative smallness, and that quantitative easing should remain as a key choice for central banks only. The outcomes proved that the ECB's unconventional monetary activism smoothened the $F X$ rate volatility during the period under review.

Our research topic is motivated by the observation that the majority of European central banks are still pursuing accommodative monetary policies despite the planned withdrawal of unconventional instruments following crisis management. However, the emerging inflationary challenges and the slowing world economy may entail the need of a well-prepared monetary policy from the central banks, which can generate additional shocks.

This study is structured as follows: the second section summarizes the theoretical background of international spill-over effects generated by monetary policy decisions, and introduces QE programs and unconventional monetary policy instruments. The third section contains the theoretical models, which will be the subjects of further analysis. The fourth section presents the analyzed dataset and the summary of gravity panel regressions, while the fifth section contains the results of the model testing.

\section{Theoretical Background}

This section summarizes the main theoretical approaches to describe spill-over effects and currency fluctuation effects of monetary policy, introduces the meanings of QE and unconventional instruments, and categorizes their application in the sample.

\subsection{The New Wave of Monetary Policy}

The position adopted in the years preceding the crisis is that the modification of short-term interest rates should be the primary tool for central banks, since by this strategy monetary policy can realize a real impact on the economy (Blanchard et al., 2015; Cecchetti and Disyatat, 2010). As prior experience has shown, shaping the inflation target causes longterm effects, in which intervention is riskier than formatting reference rates because of the unknown external shocks in the future, while the modification of policy rates has faster, 
short-term effects on the economy. Furthermore, changes in this direction shape the overall yield curve to a similar extent and direction, so that short-term money market interest rate movements also influence long-term interest rates (Blanchard et al., 2015; Cecchetti and Disyatat, 2010). Linked to this idea in the early 2000s, most of the European central banks focused on affecting short-term money market interest rates, mainly through open market operations such as government bond transactions (Bernanke and Reinhart, 2004). According to the transmission, short-term interest rates should respond to changes in inflation, although long-term interest rates should respond to the output and fiscal outlook of the member states in the eurozone, as investors sell short-term treasury bills and reinvest revenues in longer-term assets (Hamori and Hamori, 2010; Ellison and Tischbirek, 2014).

The central bank's interest rate policy exerts its influence through the monetary transmission mechanism, by which it indirectly influences foreign exchange rates through the exchange rate channel (which is particularly important for small open economies, as they are heavily dependent on the world market processes) and through spill-over effects of the measure of exchange rates affecting domestic output and inflation (Cushman and Zha, 1997; Mishkin, 2001). Over the past decade, international capital flow controls have become increasingly liberalized and capital has typically fled into safe investments, resulting in a sudden stoppage of funding for less developed economies when risk aversion reached a critical level (Krugman, 2014). Consequently, there was herding for "safe haven" currencies, which means that demand for the currencies of countries with strong economies under unfavorable foreign exchange market conditions increased due to the "safe haven" status attributed to these currencies by investors (Habib and Stracca, 2012). As a result of this phenomenon and the various shocks in the global economy, such as big changes in the monetary policy, there were serious turbulences on the $F X$ market over the past decade.

Because of the zero lower bound (ZLB) policy of central banks, which followed after 2008, it was not possible to do any further monetary easing with conventional instruments (i.e., cutting policy rates further and using traditional open market operations), so central banks adopted unconventional monetary policy (UMP) in line with their operational frameworks and mandates to deal with the problems caused by the crisis: to fight against deflation and restore financial stability (Fratzscher et al., 2014, Joyce et al., 2012). These measures included forward guidance and instruments that expanded the central banks' balance sheets or had a structural impact on their structure (Joyce et al. 2012). The first-mentioned instrument attempted to bring the expectations of market participants closer to the goals and expectations of the central bank, while the second one attempted to alter the balance sheet to meet the "lender-of-last-resort" and the "buyer-of-last-resort" functions, and entered into transactions under well-defined haircuts Acharya et al., 2018; Fratzscher et al., 2014).

During the last decade, these unconventional policies were maintained by several major 
central banks (e.g., the Fed, BOJ, BOE, ECB), although the Bank of Japan (BOJ) had already implemented large-scale government bond purchases and ZLB policy in the early 2000s during the period of the Asian financial crisis. The central banks' QE led to the large-scale asset purchase programs, which were later complemented by various credit market interventions, and their combined purpose was to reduce long-term yields, which influenced changes in foreign exchange rates and credit channels through asset prices, too (Joyce et al., 2012; Chen et al., 2012). QE programs, in many cases, inflated central banks' balance sheets - which were previously overweight in foreign currency reserves - through the growing stock of securities, thus causing changes in the asset side structure (Bernanke, 2012). This was true for Europe, despite the fact that a relatively late quantitative easing was observed on the continent.

So, the ECB's crisis-management monetary policy after 2008 shifted from lending stimulation to direct stimulation of the securities market, which, after 2014, became a part of the securities market programs and led to an increase in the stock of securities held by the ECB (and the other euro-area member banks). In doing so, reliance on the "portfolio balance effect" in Japan (i.e., to encourage investors to buy riskier securities through purely secondary government securities purchases) was replaced by primary and secondary market purchases of asset-backed securities (ABS), mortgage-backed securities (MBS), and loans to small and medium-sized enterprises by supporting securitized lending through buying securitized forms. Moreover, QE was accompanied by credit-loosening activities with the central bank lending programs. So, quantitative easing does not mean only the purchase of government securities, but also the purchase of other securities, therefore, also involving credit-granting processes, in contrast to other unconventional instruments that had wider spectrum effects (Blinder et al., 2010). Several researchers investigated the impact of these policies in different regions and, in some cases, found unexpected side effects besides their main purpose. In the next section, we summarize the effects of unconventional monetary policy through some recent studies and, in line with our study, we focus mainly on the discussion about the effects of quantitative easing.

\subsection{The Extensive Effects of UMP and QE}

The impacts of unconventional monetary policy (UMP) - which can be significantly different depending on the central banks - have been some of the most interesting topics of recent studies, which include work on the variant shocks of the examined economies and how they recovered from the crisis. Security and asset purchase programs affect financial markets and, along these lines, produce global effects beyond the country concerned. Subsequently, in making their monetary decisions, central banks have to bear in mind carefully not only the inflation target and economic growth, but also the potential spill-over effects on financial markets and commodity prices.

Like the traditional monetary transmission mechanism, the unconventional monetary instruments and QE can affect the real economy and money market conditions through a 
number of channels. As researchers have found from past observations, the scope of $\mathrm{QE}$ basically covers three segments: first, it affects the economy through its portfolio rebalancing channel, second, through its fiscal policy effect, and third, through its expectationsrelated effects. The strength of these impacts is related to the size of the monetary easing programs and the maturity structure of purchased securities and government securities by exploiting market imperfections (Bernanke et al., 2004; Woodford, 2012). From this point of view, it may be interesting and important to assess both the direct and indirect impacts, and to compare them with the expected and projected outcomes.

The spill-over effects of central bank actions generally affect capital markets through their impact on the real economy, while generating effects between these markets, too. For example, the expected decline in stock prices may indicate a weaker performance in the real sector, which may lead to a reduction in the benchmark interest rate (Jammazi et al., 2017). On the one hand, the relationship between foreign exchange and equity market rates can be examined from the point of view of the "international trade effect", according to which, the development of foreign exchange rates has a different effect on the competitiveness of export and import oriented companies, which then affects their performance and value (Aggarwal, 1981). On the other hand, stock prices influence the development of foreign exchange rates through the "portfolio rebalancing channel' 22, This has been studied by many researchers, including the effects of quantitative easing, with different results per central bank (Thornton et al., 2014; Goldstein et al., 2018). The importance of the latter channel in the dynamics of exchange rates has been confirmed by earlier studies, such as Hau and Rey (2004), where they analyzed whether the international equity returns, equity portfolio flows, and exchange rate returns are coherent with this hypothesis using international data for the five largest equity markets. Their main results showed that equity returns and portfolio rebalancing are important sources of exchange rate dynamics.

Regarding the portfolio rebalancing channel around the ECB's QE, Albertazzi et al. (2018) examined the impacts of its Expanded Asset Purchase Program (APP) — which was introduced later than the U.S. and UK programs - against the historically low inflation in the euro area. Their outcomes verified an active portfolio rebalancing channel in the euro area; in the vulnerable countries, there was a shift towards riskier securities, while in the less vulnerable countries, the effects of the portfolio rebalancing channel were observed mostly in relation to bank loans. In contrast, examining the Fed's QE programs, Thornton et al. (2014) proved, by analysing empirically the various interest rate variables and debt service measures used in the literature, that QE does not operate through the portfolio balance channel. However, investigating these mediation channels is not the focus of our research, so we do not go into further analysis.

Measuring the impact of forward guidance policy in the sample of European small

\footnotetext{
${ }^{2}$ This is the channel where investors are influenced to shift their investments away from such safe assets towards assets with higher expected returns, including lending to households and firms Albertazzi et al. 2018).
} 
open economies, Rybacki (2019) found only limited evidence that domestic forward guidance policies permanently signal the expected changes in market interest rates during the period between 2007 and 2018. However, examining the period after 2012-when financial markets began to pay more attention to the communication of central banks-Rybacki found that the expectations about interest rates were more affected by ECB policy than by domestic forward guidance when the forecast horizon is longer than four quarters. (Swanson, 2017) compared the effects of Federal Reserve UMPs in the period 2009-2015, and proved that forward guidance was more efficient than large-scale asset purchases (LSAPs) — which is part of the QE of the central bank in the broad sense - at moving short-term Treasury yields, while LSAPs were more effective than forward guidance and the federal funds rate at shifting long-term Treasury and corporate bond yields. This is in line with the notion that asset purchases had more significant effects in stimulating the real economy than forward guidance. Moreover, Swanson found that the effects of forward guidance were less tenacious (1-4 months) than the effects of the LSAP announcements. In a prior study about the Fed monetary policy, Raskin (2013) found that the date-based forward guidance policy generated a statistically significant and economically relevant adjustment in investors' attitude of the Fed FOMC' $3^{3}$ reaction function. These results support the fact that forward guidance altered perceptions of the Committee's likely reaction to emerging conditions, and the resulting reduction in the sensitivity of short-term interest rate expectations might have contributed to longer-term interest rates anchored at lower levels.

Interactions between monetary policy and currency markets were examined, mostly concentrating on direct and indirect interventions, where the volatility of exchange rates was caused by the differences between interest rate, as a side-effect of this exchange rate pressure (Stavarek, 2010), while Gabrisch (2017) studied the limitations of the monetary autonomy on an equal sample in his research about interest rate and exchange rate correlations. Neely (2015) proved through event study analysis that the Fed's unconventional monetary policy significantly diminished international long-term bond yields and spot value of the USD. He found that the strong depreciations of the USD reflected the estimations of the effects of previous equivalent monetary policy shocks, and his estimations validated that, in the case of zero lower bound, UMP can lower international long-term yields and even the value of the USD.

Regarding the connection between the ECB's QE and capital markets, Kenourgios et al. (2019) found significant differences in the correlation between bonds or stock market indices and currency forwards, among forwards during the period of the four programs (SMP, OMT, CBPP3, and PSPP). Their research showed that these programs had an influence on the correlations between financial assets through the previously mentioned portfolio rebalancing channel, and they proved that the correlations between stock index and currency forward have been more influential in the case of emerging markets.

\footnotetext{
${ }^{3}$ Federal Open Market Committee.
} 
Kucharčuková et al. (2016) investigated the macroeconomic impacts of the ECB's conventional and unconventional monetary policy to the eurozone and even its spill-over effects outside the euro area. Applying VAR models and factor analysis, their results proved that the transmission mechanism of unconventional monetary policy differs a lot from the case of conventional policies in the euro area. One of their main findings is that, under UMP, exchange rates responded faster, and these responses for several countries moved in the contrary direction than under conventional monetary policy outside the eurozone.

With divergent results from the previous study, Inoue and Rossi (2019) investigated the spill-over effects on the $F X$ rates of the UK, Canada, Europe, and Japan vis-à-vis the USD. Their results showed that the Fed's unconventional instruments caused a devaluation of the spot nominal exchange rate in both conventional and unconventional monetary policy periods, despite the fact that the responses of the exchange rate were significantly different according to the changes in people's expectations. They also demonstrated that monetary policy shocks show considerable heterogeneity over time, and their impact depends on whether they influence market expectations. Analysing further the exchange rate dynamics under unconventional monetary policy, and using DSGE models and the Nash equilibrium as a self-oriented case, Adler et al. (2019) revealed that UMP weakened the currency depreciation in response to negative shocks. Moreover, they found that under zero lower bound, central banks usually apply unconventional instruments, and stabilized $F X$ rates and direct exchange rate controls together.

Exploring the relationship between UMP, $F X$ risk premia, and term premia, Rogers et al. (2018) established that all three kinds of easing monetary policy shocks (target surprises, forward guidance surprises, and asset purchase surprises) lowered the value of the USD and they showed that forward guidance policy boosted foreign exchange risk premia, while asset purchases reduced them. Fratzscher et al. (2016) examined the impacts generated by the UMP of the ECB using panel models. Their results showed that these unorthodox policies made beneficial impressions and positive spill-overs on global financial markets in the short term with increasing asset prices, and reduced market fragmentation in bond markets while lowering the global price of risk.

A detailed analysis was obtained on the sampled central banks to check the application of various unconventional monetary instruments, and to see what kind of discretionary $F X$ regimes were introduced against the excessive appreciation $(F X$ ceiling or stabilized arrangements as suggested by the IMF (2017). It includes a summary about the balance of portfolio investments in the analyzed period. There were common instruments like forward guidance, $F X$ swap, or negative interest policy, while asset purchase programs were important mainly for the ECB, SR, and later for the MNB. While Swiss and Danish central banks were faced with a positive portfolio investment balance, the Swedish central bank and the ECB experienced a balanced situation. Denmark has followed a tight peg since the 1990s, while Switzerland adopted an upper ceiling between 2012 and 2015, and 
Czechia maintained a similar regime between 2013 and 2017.

In light of all the above mentioned examinations on the topic, we aimed to do further research about the effects of unconventional monetary developments on foreign exchange rates over the past decade with a methodology that has not been applied before to assess the effects of monetary policy in a less studied sample: European small open economies that are non-eurozone members.

\section{Theoretical Models}

This section contains our theoretical models. However, before quantifying the effects of QE and UMP on foreign exchange rate volatility, we look at the factors and correlations that can explain exchange rate fluctuations in the special case of small open economies under the shadow of the eurozone.

\subsection{Model Variables}

The asset side of the central bank balance sheet $\left(T A_{t, i}\right)$ at time $t$ in a country $i$ consists mainly of the $F X$ reserves $\left(F X_{t, i}\right)$, loans for the domestic banking system $\left(L_{t, i}\right)$, and accumulated securities $\left(S_{t, i}\right)$, traditionally with a dominance of the reserves. The introduction of unconventional monetary policies was the response to the bursts of deflationary waves and deteriorating financial stability during the global financial crisis, with instruments focusing on zero interest rates (zero lower bound, ZLB), long-term lending, and asset purchases of even currency swap agreements. These instruments were combined into programs to enhance the transmission mechanism, to smoothen the yield curve, or to reduce a specific asset's risk premium (Borio and Disyatat, 2010), commonly combined with forward guidance to anchor expectations. The lending or security programs under QE had their structural impact on a central bank's balance sheet by transforming the former balanced or $F X$ reserve-focused based balance sheet towards a more activist setup, as central banks became not only the lenders but also the market makers of last resort (Bernanke and Reinhart, 2004; Kool and Thornton, 2012). All these structural changes can be captured in the ratio of the main assets (1):

$$
L S F X_{t, i}=\frac{L_{t, i}+S_{t, i}}{F X_{t, i}}
$$

Central banks following floating exchange rate regimes managed directly exchange rates via peg-like regimes or indirectly under floating-like approaches. Most of the countries outside the eurozone maintain independent floating regimes under liberalized capital flows to meet the Mundell-Fleming trilemma and to maintain some sort of autonomy. The uncovered interest rate parity (2) describes foreign exchange rate changes $\left(\Delta e_{t}\right)$ by the 
differentials in their interest rates $(r)$ on a well-performing market (Herger, 2016):

$$
\Delta e_{t, i}=\omega_{t, i}+\alpha \cdot \Delta\left(r_{t, i}-r_{t, f}\right)+\varepsilon_{t, i}
$$

Domestic prices and inflation are also affected by changes in foreign exchange rates due to their role in the monetary transmission mechanism and its spill-over effects. In the specific case of small open economies, these effects are more important, whereas, as a result of these features, exchange rate fluctuations have a stronger impact on them and also affect the key policy rate. This $F X$ variable is also included in the Taylor rule supplemented in their case; this phenomenon can be partly explained due to "fear of floating" behavior, which means that small open economies' central banks usually have non-declared exchange rate targets against their floating exchange rate regimes (Calvo and Reinhart, 2002; Svensson, 2000; Taylor, 2001, 1993). The flight to the safety phenomenon can have distorting effects on currency markets due to the sudden and excessive demand for safer assets, especially when stock market instruments change and expectations decrease (Bekaert et al. 2009; Fratzscher, 2009). The 2008 Great Financial Crisis (GFC) launched a similar flight with the sudden stops of the riskier emerging countries. Therefore, currency volatility can be an appropriate indicator to describe the appearance of unwanted turbulences.

Consequently, central banks in small and open economies are more exposed to their environment since their funding conditions are more determined by market sentiment. Market uncertainties about $F X$ valuation can be interpreted as a benchmark to capture this behavior. It can be easily assumed that the implementation of unconventional instruments requires some robustness and resilience from the above-mentioned external effects.

\subsection{Model Setup}

Gravity models capture the dependent variable on the basis of relative size differences, which is commonly used to study trade relations among developed and developing countries. However, this approach can be adapted for the asymmetric relations among the key and other central banks, which operate mostly in small and open economies. Bank of International Settlements (2011) states that the degree of freedom of monetary policy can be limited by global liquidity flows and key central banks'decisions, reducing the autonomy of the other central banks. These impacts can be even more important around the eurozone, where "smallness" can be captured through differences in the population, economic output, or what is much more relevant to our subject: in the size of the central bank balance sheet. Since the balance sheet size refers to the capabilities and activities of the monetary policy and its size can represent the relative differences in the economic output, it can be an excellent proxy variable to represent relative size differences.

The core concept of this paper is that it can be harder to value an exchange rate 
in a smaller economy, so the level of volatility should refer to relative size differences as well as the implementation of conventional and unconventional instruments, which will be appreciated differently depending on the market. Our model (3) states that floating exchange rates should react to these phenomena with elevated volatility, which can be described by differences in the size of the central bank balance sheet, interest rates, lending activity, and macro-variables like output gap and deviation from the inflation target. Therefore:

$$
\begin{aligned}
\sigma_{F X, t, i} & =\text { const }+\alpha_{1} \cdot \Delta \ln \left(T A_{t, \mathrm{ECB}}-T A_{t, i}\right)+\alpha_{2} \cdot\left(10 Y_{t, i}-10 Y_{t, D E}\right)+ \\
& +\alpha_{3} \cdot \Delta\left(\frac{L+S}{F X_{t, \mathrm{ECB}}}-\frac{L+S}{F X_{t, i}}\right)+\alpha_{4} \cdot\left(o p g_{t, \mathrm{EUR}}-o p g_{t, i}\right)+ \\
& +\alpha_{5} \cdot\left(\pi d_{t, \mathrm{EUR}}-\pi d_{t, i}\right)+\alpha_{6} \cdot \text { dummy }_{F X \text { regime }, t, i}+ \\
& +\alpha_{7} \cdot \text { dummy }_{\mathrm{ESM}, t, i}+\alpha_{8} \cdot \text { dumm }_{\mathrm{IMF}, t, i}+\varepsilon_{t, i}
\end{aligned}
$$

where $\sigma_{F X}$ denotes the quarterly conditional variances (estimated with a GJR-GARCH $(1,1,1)$ model $)$, ln represents natural logarithm and $\Delta$ denotes the first difference, $T A$ is the size of the central bank balance sheet, the $10 Y$ difference represents the yield premium among 10-year German and ith countries' 10-year government bonds, and the $\frac{L+S}{F X}$ ratio captures the activity of the central bank ( $L$ : overall domestic lending, $S$ : domestic security holding, and $F X$ : foreign exchange reserve). This $L S F X$ variable has been introduced to illustrate the effects of the structural changes of the central bank balance sheet, which can be affected under quantitative easing. Foreign exchange reserves were dominant in the balance sheets, but currency devaluations (like in the Hungarian case) or interventions (like in the Swiss case) had their footprint on their levels as well. The differences among macroeconomic conditions were presented with the opg output gap and the $\pi d$ deviation from the inflation target as a consideration of the transmission mechanism. Some of the sampled countries (Czechia and Switzerland) implemented stabilized arrangements on a temporary basis, with Denmark maintaining its $2.25 \%$ band; this behavior was represented by the dummy variable. The shock of the sovereign debt crisis in the eurozone was represented with two dummy variables, each of them representing the capital transfers from the International Monetary Fund (IMF) and from the European Stability Mechanism (ESM) to the member states.

The specification in (3) was considered as Model 5, while the other, reduced forms (Models 1-4) analyzed the individual relations to improve model robustness.

Model 1:

$$
\begin{aligned}
\sigma_{F X, t, i} & =\text { const }+\alpha_{1} \cdot \Delta \ln \left(T A_{t, \mathrm{ECB}}-T A_{t, i}\right)+ \\
& +\alpha_{6} \cdot \text { dummy }_{F X \text { regime }, t, i}+\alpha_{7} \cdot d u m m y_{\mathrm{ESM}, t, i}+\alpha_{8} \cdot d u m m y_{\mathrm{IMF}, t, i}+\varepsilon_{t, i}
\end{aligned}
$$


Model 2:

$$
\begin{aligned}
\sigma_{F X, t, i} & =\mathrm{const}+\alpha_{1} \cdot \Delta \ln \left(T A_{t, \mathrm{ECB}}-T A_{t, i}\right)+\alpha_{2} \cdot\left(10 \mathrm{Y}_{t, i}-10 \mathrm{Y}_{t, D E}\right)+ \\
& +\alpha_{6} \cdot \text { dummy }_{F X \text { regime }, t, i}+\alpha_{7} \cdot d u m m y_{\mathrm{ESM}, t, i}+\alpha_{8} \cdot d u m m y_{\mathrm{IMF}, t, i}+\varepsilon_{t, i}
\end{aligned}
$$

Model 3:

$$
\begin{aligned}
\sigma_{F X, t, i} & =\text { const }+\alpha_{1} \cdot \Delta \ln \left(T A_{t, \mathrm{ECB}}-T A_{t, i}\right)+\alpha_{3} \cdot \Delta\left(\frac{L+S}{F X_{t, \mathrm{ECB}}}-\frac{L+S}{F X_{t, i}}\right)+ \\
& +\alpha_{6} \cdot \text { dummy }_{F X \text { regime }, t, i}+\alpha_{7} \cdot \text { dummy }_{\mathrm{ESM}, t, i}+\alpha_{8} \cdot d u m m y_{\mathrm{IMF}, t, i}+\varepsilon_{t, i}
\end{aligned}
$$

Model 4:

$$
\begin{aligned}
\sigma_{F X, t, i} & =\text { const }+\alpha_{1} \cdot \Delta \ln \left(T A_{t, \mathrm{ECB}}-T A_{t, i}\right)+ \\
& +\alpha_{2} \cdot\left(10 \mathrm{Y}_{t, i}-10 \mathrm{Y}_{t, D E}\right)+\alpha_{3} \cdot \Delta\left(\frac{L+S}{F X_{t, \mathrm{ECB}}}-\frac{L+S}{F X_{t, i}}\right)+ \\
& +\alpha_{6} \cdot \text { dummy }_{F X \text { regime }, t, i}+\alpha_{7} \cdot \text { dummy }_{\mathrm{ESM}, t, i}+\alpha_{8} \cdot \text { dummy }_{\mathrm{IMF}, t, i}+\varepsilon_{t, i}
\end{aligned}
$$

Model 1 was the most truncated representation to test the core concept of the gravity model to show how the changes of the balance sheet asymmetries matter, while Model 2 added uncovered interest rate parity to see how the volatility was smoothed through the interest rate channel of the monetary policy. Model 3 added and tested the structural changes of the central bank balance sheet, representing the changes in the usage of different monetary policy instruments, while Model 4 combined the conventional (interest rate) and unconventional (balance sheet) instruments of the monetary policy.

\subsubsection{Preliminary Expectations}

This study anticipates the following outcomes for model coefficients. An increasing difference among balance sheet sizes can represent how the unconventional boom at the ECB was not followed by the rest of the central banks, or the level of volatility was high in the cases when they were trying to catch up $\left(\alpha_{1}>0\right)$. Interest premiums $\left(10 Y_{D E}<10 Y_{i}\right)$ can guide investments and capital flows; therefore, they can be also a source of volatility $\left(\alpha_{2}>0\right)$. The idea that unconventional monetary policy should be a tool only for the key central banks was also represented in the changes of the $L S F X$ ratio difference, where the ECB's $L S F X$ ratio dramatically increased with the intention of security market stabilization $\left(\alpha_{3}<0\right)$, but an unconventional catch-up would take its toll in an open and small economy. Cross-country differences in the state of economic conditions (like output gap and deviations from the targeted inflation) can be interpreted as countries are in various conjuncture states, fueling the volatility as well $\left(\alpha_{4,5}>0\right)$. The implementation of pegged or stabilized regimes or rescue packages should smooth the volatility $\left(\alpha_{6,7,8}<0\right)$. 


\section{Data and Methods}

This section first presents the sources and the developments in the analyzed dataset. Then, it summarizes the methodological backgrounds of the applied gravity panel regression. After the defining gravity models and their applied form, fixed and random effect models are presented. The aim of this paper is to analyze the background of currency volatility, which can be estimated via GARCH models. Panel regressions were conducted in EViews 11 software, while GJR-GARCH estimations were done in MATLAB 2014a software, using Kevin Sheppard's MFE toolbox.

\subsection{Data}

Data (Table 1) was collected mainly from central bank databases, Eurostat and Stooq.com, covering the 2007 Q1-2018 Q1 interval. All FX data used SDR as a denominator to minimize the possible bias of external central banks (especially the U.S. Fed). Balance sheet data was denominated in EUR based on the same consideration. Interest premiums were calculated against German 10-year government bond yields. The 10-year maturity was preferred because it is less affected by liquidity turbulences or monetary policy than shorter maturities. The output gap was calculated based on the industrial production index against its HP-filtered values, following Demir (2014) $\left(O P G_{t, i}=\right.$ $\left.H P_{I P, t, i, \lambda=100}-H P_{I P, t, i, \lambda=1600}\right)$, where the end-point disturbances were managed by the exclusion of the last two observations (namely, Q2 and Q3 in 2019).

Table 1: Data sources

\begin{tabular}{ll}
\hline Variable (2007Q1-2018Q1) & Source \\
\hline$F X$ rates (denominated in SDR) & stooq.com \\
Interest rate: 10 year sovereign yield (10Y) & stooq.com \\
Output gap (industrial production index, HP filter) & OECD, Eurostat \\
Deviation from inflation target & central banks, Eurostat \\
Balance Sheet size (in SDR) & central banks (Balance sheet data) \\
$L S F X=(L+S) / F X$ reserve ratio & central banks (Balance sheet data) \\
$F X$ regime dummy & central banks (Annual reports) \\
IMF dummy & IMF website (country reports) \\
ESM dummy & ESM website (lending reports) \\
\hline
\end{tabular}

Source: Authors' edition

The foreign exchange market volatility reached its peak around 2008 during the global financial crisis, presenting higher values for Visegrad countries (Czechia, Hungary, Poland, and Slovakia) (Figure 1), and was followed by depreciation and higher interest rates in this region. This was followed by turbulent periods, as well, until the situation stabilized after 2014, possibly due to the introduction of the European Stability Mechanism and the widespread asset purchase programs of the ECB. 
Figure 1: Quarterly mean of weekly conditional variances (GJR-GARCH(1,1,1) estimations, SDR denominator)

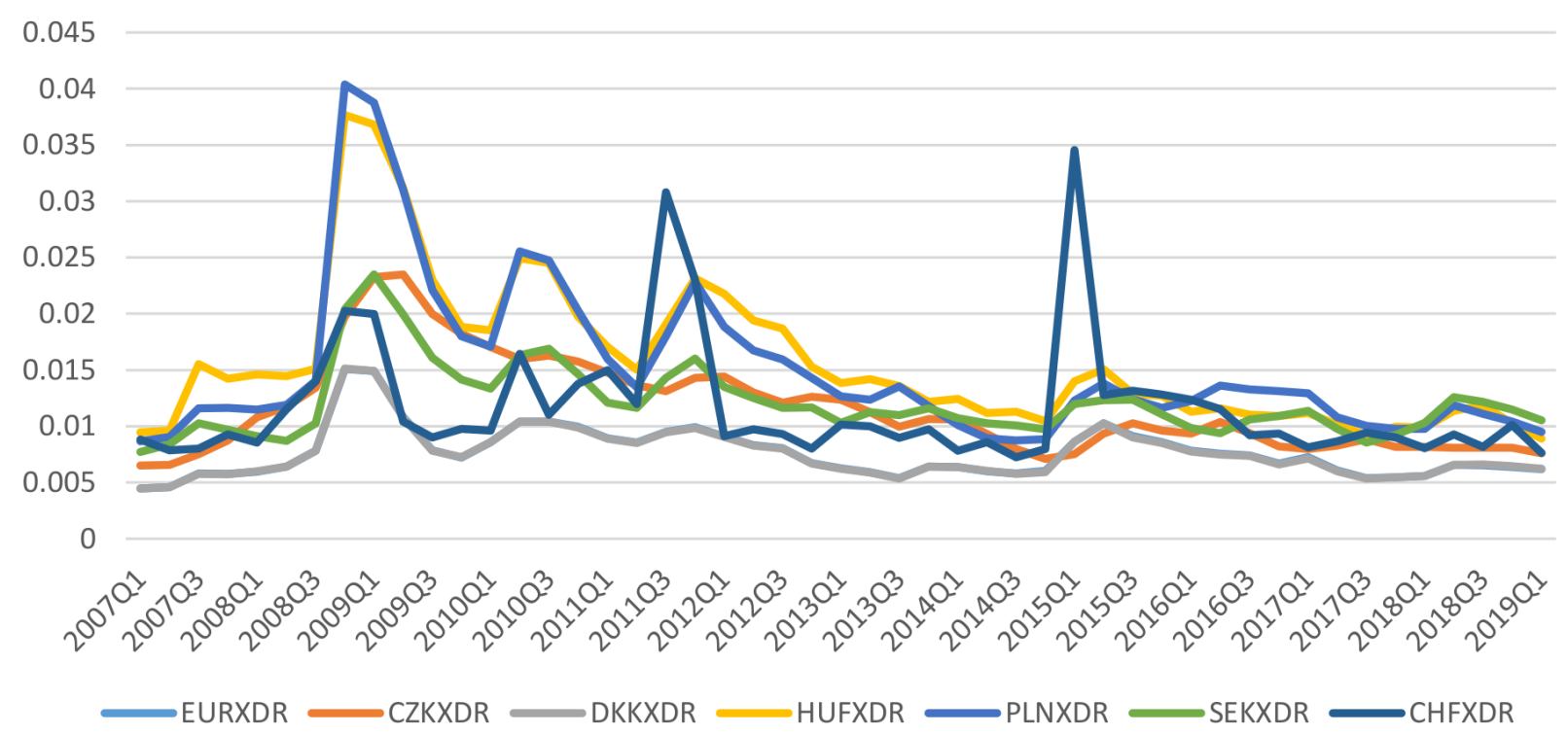

Sources: Authors' edition, MATLAB 2014b, MFE Toolbox

Figure 2: Central bank balance sheet size in million SDR equivalent

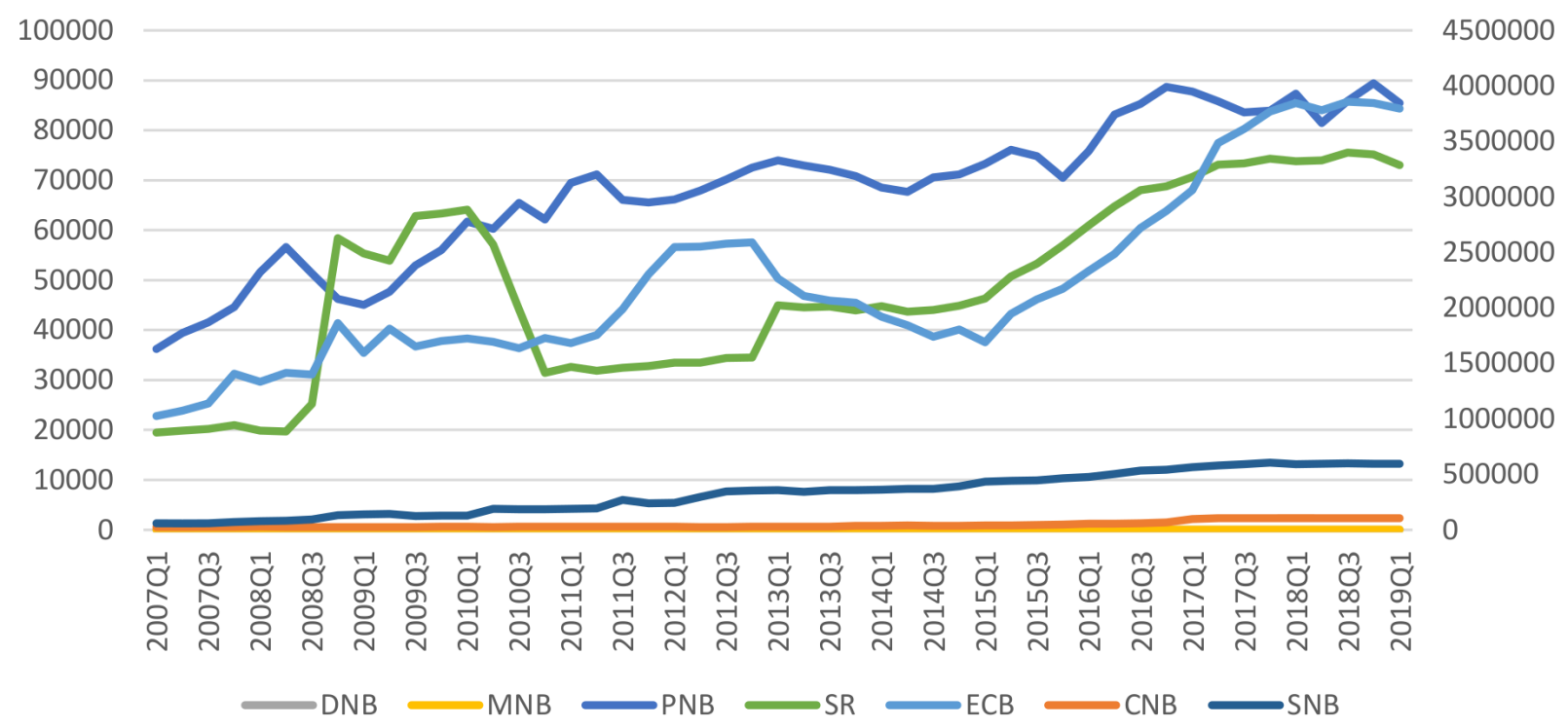

Sources: central banks' balance sheet database

Central bank balance sheets had a common SDR denominator, and presented a continuous but country-specific increase in the sample. Its value can be affected by lending expansion, security accumulation programs, and foreign exchange reserve changes due to interventions (Figure 2). The ECB presented a significant rise after the introduction of its QE program (as well as in Sweden), while the Swiss and Czech national banks fought against excessive appreciation. 
Figure 3: $L S F X$ ratio (lending and security accumulation to $F X$ reserves)

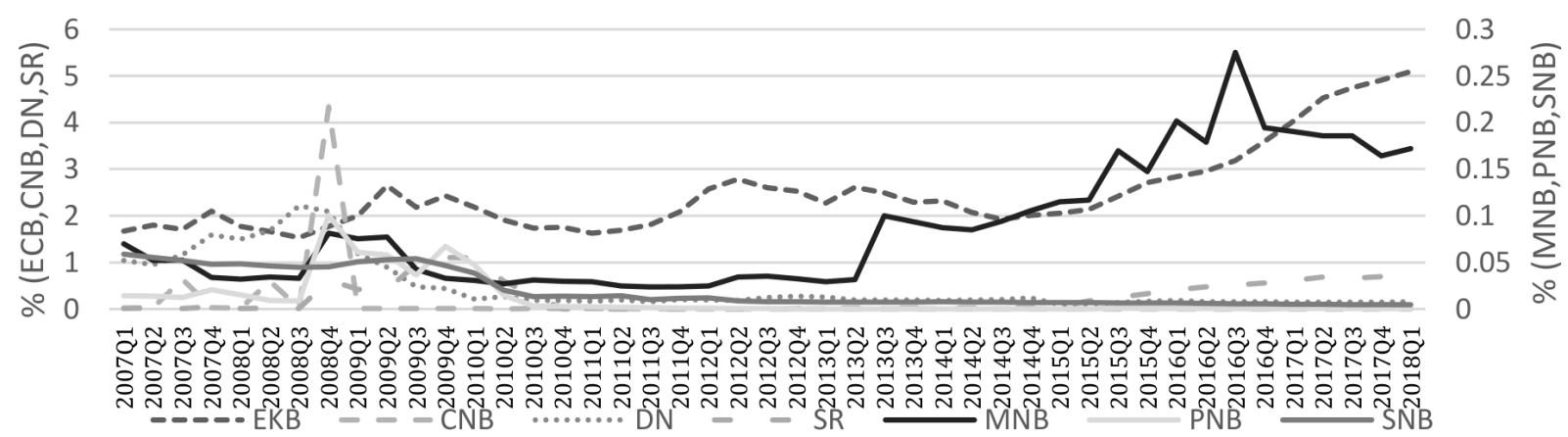

Source: Authorial computation, based on central bank data

Structural changes are represented better by the $L S F X$ ratio (Figure 3), presenting an expansionist subset with the ECB, CNB, DN, and SR, and a more conservative and $F X$ reserve oriented $\mathrm{MNB}, \mathrm{PNB}$, and $\mathrm{SNB}$. This data underlines the importance of further analysis because it supports the intuition of the interactions among $F X$ volatility and monetary policy.

\subsection{Methods}

Our theoretical model was inspired by the setup of gravity models, where the conditional volatility is tested against the relative size and the accommodating behavior of the underlying central banks, as well as macroeconomic differences in a panel regression analysis. Gravity models (8) are generally used as a tool to analyze trade relations among the core and periphery, using log-linear models (Greene, 2003):

$$
\ln y=\mathrm{const}+\alpha_{1} \cdot \ln X_{1}+\cdots+\alpha_{n} \cdot \ln X_{n}+\varepsilon
$$

where for all $k$ variables $(1 \leq k \leq n) X_{k}>0$ and for $i$ countries $(1 \leq k \leq m) X_{k}=$ $x_{k, \text { core }}-x_{k, i}$.

This model is widely applied in the analysis of trade relations (Van Bergeijk and Brakman, 2010), and it can be combined with exchange rate volatility (Šimáková, 2016). However, some of our variables (like deviation from inflation target and output gap) could be considered on the $-\infty<x_{k, i}<+\infty$ scale, so logarithm could not apply to them. In other cases, the strict $x_{k, \text { core }}-x_{k, i}>0$ requirement failed temporally, providing a truncated log-linear model (9):

$$
\ln y=\mathrm{const}+\alpha_{1} \cdot \ln X_{1}+\alpha_{2} \cdot Z_{2}+\cdots+\alpha_{n} \cdot Z_{n}+\varepsilon
$$

where $Z_{k}=E\left(x_{k, \text { core }}-x_{k, i}\right) \cong 0$.

Panel data analysis describes the relationship among the dependent $(y)$ and explana- 
tory variables $(x)$ in cross-sectional $(N)$ and time $(T)$ dimensions with an assumed nonobserved variable $\left(u_{i}\right)$. Pooled OLS (10) is the simplest form of panel regressions when individual cross-sectional or time-specific effects are missing $\left(u_{i}=0\right)$ :

$$
y_{i, t}=\omega+\beta X_{i, t}^{\prime}+\varepsilon_{i, t} .
$$

Poolability investigates slopes that are the same across group or over time, which can be tested through an extension of the Chow test when the null hypothesis of the slope of a regressor is the same regardless of individual for all $k$ regressors $H_{0}: \beta_{i, k}=\beta_{k}$. In cases where an $X_{i}$ variable correlates with the non-observed $u_{i}$, the application of the fixed effect model $(\mathrm{FE})$ will be required, as the variables are different, but the time-invariant (11) and the null hypothesis of the Crow test was rejected:

$$
y_{i, t}=\omega+u_{i}+\beta X_{i, t}^{\prime}+\varepsilon_{i, t}
$$

According to the null hypothesis of the Hausman test, there is no correlation between the $u_{i}$ and $X_{i}$ variables, which means we prefer the FE model for $p>0.05$ cases. Otherwise, we have to apply the random effect model (RE), which assumes no correlation, as all variables are time-variant and different from each other (12):

$$
y_{i, t}=\omega+\beta X_{i, t}^{\prime}+\left(u_{i}+\varepsilon_{i, t}\right) .
$$

Panel regressions require stationary input, which was tested with the $\operatorname{Im}$ et al. (2003) tests $(p<0.05)$.

Common events such as recessions, global shocks, or the worldwide effects of the global financial and economic crisis can potentially affect the entire sample, initiating a considerable cross-sectional interdependency across the cross-sectional unit, their regressors, and the error terms, which can result in misleading inferences. Cross-sectional dependence was tested with Pesaran CD to be sure there is no cross-sectional dependence (correlation) in the residuals $(p>0.05)$ (Pesaran, 2007).

Conditional volatility can be estimated by $\operatorname{GARCH}(p, q)$ models, especially with one of its asymmetric derivative for currencies like the $\operatorname{GJR}-\operatorname{GARCH}(p, o, q)$ model (13):

$$
\begin{aligned}
& \left\{\begin{array}{l}
S_{t-i}^{-}=1, \text { if } \varepsilon_{t-i}<0 \\
S_{t-i}^{-}=0, \text { if } \varepsilon_{t-i} \geq 0
\end{array}\right. \\
& \sigma_{t}^{2}=\omega+\sum_{i=1}^{p} \alpha_{i} \varepsilon_{t-i}^{2}+\sum_{i=1}^{o} \gamma_{i} S_{t-1}^{-} \varepsilon_{t-i}^{2}+\sum_{i=1}^{q} \beta_{i} \sigma_{t-i}^{2}
\end{aligned}
$$

where $\alpha_{1}>0(i=1, \ldots, p), \gamma_{i}+\alpha_{i}>0(i=1, \ldots, o), \beta_{i} \geq 0(i=1, \ldots, q), \alpha_{i}+0,5 \gamma_{i}+$ $\beta_{k}<1(i=1, \ldots, p, j=1, \ldots, o, k=1, \ldots, q)$ (Greene, 2003). 


\section{Results}

The panel data has no unit roots according to the results of the Im et al. (2003) tests (Table 2), so it was suitable as an input for the panel regression (Table 2) after the first differences of the $\Delta \ln \left(T A_{t, \mathrm{ECB}}-T A_{t, i}\right)$ and $\left(\frac{L+S}{F X}_{t, \mathrm{ECB}}-\frac{L+S}{F X}_{t, i}\right)$ variables since they proved to be $I(1)$ processes.

Table 2: Im, Pesaran, and Shin Panel unit root test results

\begin{tabular}{lccccc}
\hline & \multicolumn{2}{c}{ level } & \multicolumn{4}{c}{ first differential } \\
variable & W statistic & $\mathrm{P}$ & W statistic & $\mathrm{P}$ & \\
\hline$\sigma_{F X, t, i}$ & -3.57201 & 0.0002 & -10.2901 & 0.0000 & $\mathrm{I}(0)$ \\
$\ln \left(T A_{t, \mathrm{ECB}}-T A_{t, i}\right)$ & 1.2431 & 0.8931 & -5.0469 & 0.0000 & $\mathrm{I}(1)$ \\
$\left(10 \mathrm{Y}_{t, i}-10 \mathrm{Y}_{t, \mathrm{DE}}\right)$ & -2.0811 & 0.0187 & -9.6038 & 0.0000 & $\mathrm{I}(0)$ \\
$\sigma_{\left(10 Y_{t, i}-10 Y_{t, \mathrm{DE}}\right), t, i}$ & -5.5961 & 0.0000 & -12.5509 & 0.0000 & $\mathrm{I}(0)$ \\
$\left(\frac{L+S}{F X} t, \mathrm{ECB}-\frac{L+S}{F X}{ }_{t, i}\right)$ & 3.6061 & 0.9998 & -6.4685 & 0.0000 & $\mathrm{I}(1)$ \\
$\left(\operatorname{opg}_{t, \mathrm{EUR}}-\mathrm{opg}_{t, i}\right)$ & -17.2193 & 0.0000 & -14.9411 & 0.0000 & $\mathrm{I}(0)$ \\
$\left(\pi d_{t, \mathrm{EUR}}-\pi d_{t, i}\right)$ & -3.0568 & 0.0011 & -7.4872 & 0.0000 & $\mathrm{I}(0)$ \\
\hline
\end{tabular}

Source: authors' calculation

The Crow test results (Table 3) suggested the use of the pooled OLS, where the inclusion of the $\left(10 \mathrm{Y}_{t, i}-10 \mathrm{Y}_{t, \mathrm{DE}}\right)$ and all the dummy variables helped to avoid the occurrence of cross-sectional dependence. The exceptions were the cases of Models 1 and 3, where this variable was not included. Durbin-Watson test statistics were inside the tolerance-band (1.8-2.2) in the remaining models $(2,4,5)$.

The coefficients met their anticipated levels: high volatility was the product of central bank balance sheet relative size differences and interest premium, while the ECB's unconventional monetary activism and the implementations of $F X$ bands or ceilings had the opposite effects. Crisis management or macroeconomic differences had a neutral impact on volatility levels. These results support the idea that currencies around the eurozone have naturally high levels of volatility due to their relative smallness, as well as that quantitative easing should remain as the key central banks'choice only. Meanwhile, it is possible to adapt the gravity model setup to analyze this topic, and the $L S F X$ ratio was able to represent well the structural differences among various central banks' balance sheets.

We had similar results when the conditional standard deviation of the yield premium was implemented (Appendix 1), but all those models suffered from cross-sectional dependency, so not even the inclusion of three different dummy variables were enough to settle this problem, even if we were using FE or RE models instead of pooled OLS. 


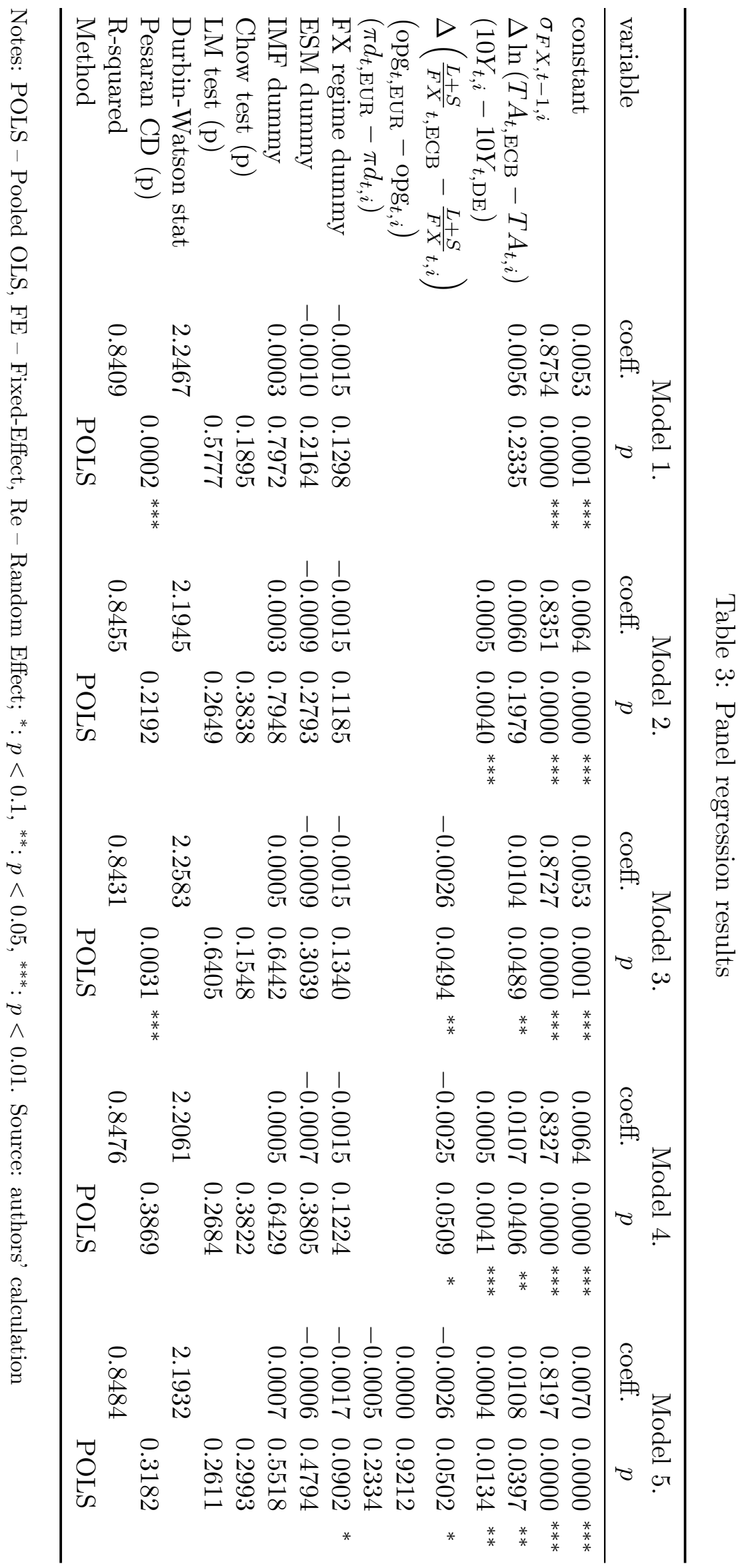




\section{Conclusion}

In our study, we examined the effects of the economic environment created by the emergence of unconventional monetary policies on the volatility of foreign exchange rates through the examples of European, non-eurozone central banks and the European Central Bank using gravity panel models. The aim of this paper was to examine the background of currency volatility and find out which factors influenced the changes in $F X$ rates, in addition to the new instruments and ZLB. Based on the sample of these seven central banks, we observed a more intense central bank activity in accordance with the peculiarities of the diverse financial institutions of different countries.

Most of the European currencies are considered as floating currencies, despite the openness and the relative size of their economy, compared with the eurozone. This paper studied the impacts of the differences in relative size through an adapted version of the gravity models. We assumed that currencies tend to fluctuate more when a central bank is smaller, does not provide significant interest premiums, and follows unconventional practices, which makes currency valuation even more complicated (symbolized by a high volatility). Considerations about safe havens leading towards excessive appreciation under turbulent times were captured through the maintenance of stabilized arrangements. These assumptions were tested and accepted after multiple model comparisons, and showed that the central bank balance sheet structure can be considered as a secondary instrument after interest rate parity during currency valuation. On the other hand, market sentiment and relative size can act against excessive volatility.

\section{A Appendix 1: Robustness Check}

The original model (3) setup was tested with the implementation of the conditional standard deviation of the interest premium (14):

$$
\begin{aligned}
\sigma_{F X, t, i} & =\text { const. }+\alpha_{1} \cdot \Delta \ln \left(T A_{t, \mathrm{ECB}}-T A_{t, i}\right)+\alpha_{2} \cdot \sigma_{\left(10 Y_{t, i}-10 Y_{t, \mathrm{DE}}\right), t, i}+ \\
& +\alpha_{3} \cdot \Delta\left(\frac{L+S}{F X}_{t, \mathrm{ECB}}-\frac{L+S}{F X}{ }_{t, i}\right)+\alpha_{4} \cdot\left(\operatorname{opg}_{t, \mathrm{EUR}}-o p g_{t, i}\right)+ \\
& +\alpha_{5} \cdot\left(\pi d_{t, \mathrm{EUR}}-\pi d_{t, i}\right)+\alpha_{6} \cdot d_{u m m} y_{F X \text { regime }, t, i}+ \\
& +\alpha_{7} \cdot \text { dummy }_{\mathrm{ESM}, t, i}+\alpha_{8} \cdot d_{u m m y_{\mathrm{IMF}, t, i}}+\varepsilon_{t, i}
\end{aligned}
$$

All the sub-models and methodical approaches were the same as in the main text. The results were highly similar even under different panel models, but all of them were infested by the cross-sectional dependency. 


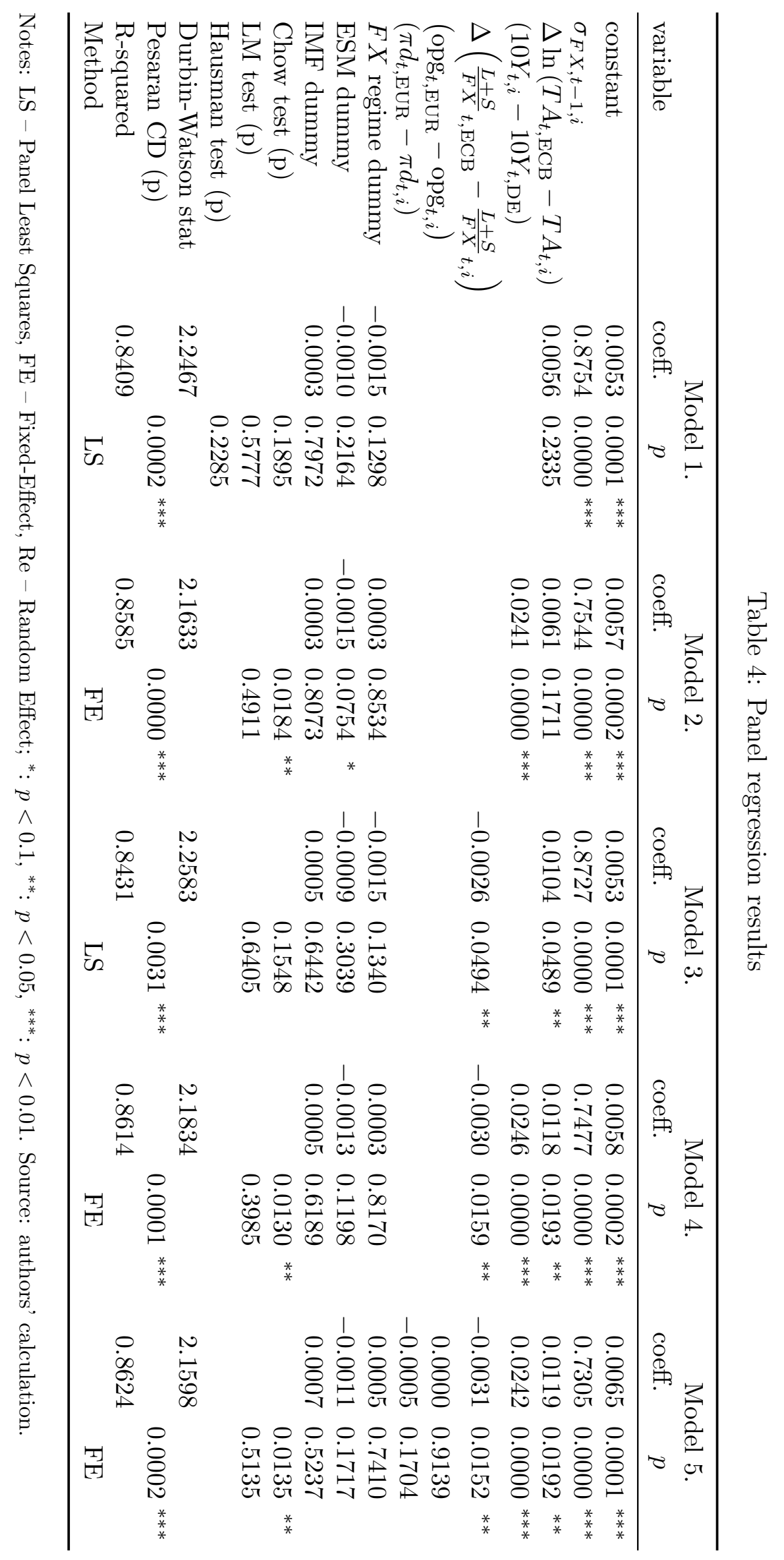




\section{References}

Acharya, V. V., Pierret, D., and Steffen, S. (2018). Lender of last resort, buyer of last resort, and a fear of fire sales in the sovereign bond market. $Z E W$-Centre for European Economic Research Discussion Paper, 16-019:18-35.

Adler, G., Lama, R., and Medina, J. P. (2019). Unconventional policies and exchange rate dynamics. Journal of International Money and Finance, 95:402-423.

Aggarwal, R. (1981). Exchange rates and stock prices: A study of the US capital markets under floating exchange rates. Akron Business and Economic Review, 3(9).

Albertazzi, U., Becker, B., and Boucinha, M. (2018). Portfolio rebalancing and the transmission of large-scale asset programmes: evidence from the euro area. Technical report, ECB Working Paper, No 2125.

Altavilla, C., Carboni, G., and Motto, R. (2015). Asset purchase programmes and financial markets: lessons from the euro area. Technical report, ECB Working Paper Series, No 1864.

Bank of International Settlements (2011). Global liquidity - concept, measurement and policy implications. Technical Report 45, Bank of International Settlements CGFS Publications.

Bekaert, G., Engstrom, E., and Xing, Y. (2009). Risk, uncertainty, and asset prices. Journal of Financial Economics, 91(1):59-82.

Bernanke, B., Reinhart, V., and Sack, B. (2004). Monetary policy alternatives at the zero bound: An empirical assessment. Brookings papers on economic activity, 2004(2):1-100.

Bernanke, B. S. (2012). Monetary Policy since the Onset of the Crisis. Remarks at the Federal Reserve Bank of Kansas City Economic Symposium, Jackson Hole, Wyoming, 2012.09.31. Online: http://www.federalreserve.gov/newsevents/ speech/bernanke20120831a.pdf

Bernanke, B. S. and Reinhart, V. R. (2004). Conducting monetary policy at very low short-term interest rates. American Economic Review, 94(2):85-90.

Blanchard, O., Cerutti, E., and Summers, L. (2015). Inflation and activity-two explorations and their monetary policy implications. Technical report, National Bureau of Economic Research, No w21726.

Blinder, A. S. et al. (2010). Quantitative easing: entrance and exit strategies. Federal Reserve Bank of St. Louis Review, 92(6):465-479. 
Borio, C. and Disyatat, P. (2010). Unconventional monetary policies: an appraisal. The Manchester School, 78:53-89.

Calvo, G. A. and Reinhart, C. M. (2002). Fear of floating. The Quarterly Journal of Economics, 117(2):379-408.

Cecchetti, S. G. and Disyatat, P. (2010). Central bank tools and liquidity shortages. Economic Policy Review, 16(1):29-42.

Chen, H., Cúrdia, V., and Ferrero, A. (2012). The macroeconomic effects of large-scale asset purchase programmes. The Economic Journal, 122(564):F289-F315.

Cushman, D. O. and Zha, T. (1997). Identifying monetary policy in a small open economy under flexible exchange rates. Journal of Monetary Economics, 39(3):433-448.

Demir, İ. (2014). Monetary policy responses to the exchange rate: Empirical evidence from the ECB. Economic Modelling, 39(4):63-70.

Draghi, M. (2019). Twenty Years of the ECB's monetary policy. In Speech by Mario Draghi, President of the ECB, ECB Forum on Central Banking, Sintra, 18 June 2019. Online: https://www.ecb.europa.eu/press/key/date/2019/html/ecb.sp190618 \{\} ec4cd2443b.en.html.

Ellison, M. and Tischbirek, A. (2014). Unconventional government debt purchases as a supplement to conventional monetary policy. Journal of Economic Dynamics and Control, 43:199-217.

Fratzscher, M. (2009). What explains global exchange rate movements during the financial crisis? Journal of International Money and Finance, 28(8):1390-1407.

Fratzscher, M., Duca, M. L., and Straub, R. (2014). ECB Unconventional Monetary Policy Actions: Market Impact, International Spillovers and Transmission Channels. Technical report, Policy Research Working Paper, (6820).

Fratzscher, M., Duca, M. L., and Straub, R. (2016). ECB unconventional monetary policy: Market impact and international spillovers. IMF Economic Review, 64(1):36-74.

Gabrisch, H. (2017). Monetary policy independence reconsidered: evidence from six noneuro members of the European Union. Empirica, 44(3):567-584.

Goldstein, I., Witmer, J., and Yang, J. (2018). Following the money: Evidence for the portfolio balance channel of quantitative easing. Technical Report 2018-33, Bank of Canada Staff Working Paper.

Greene, W. H. (2003). Econometric Analysis. Prentice Hall. Pearson. New Jersey. 
Habib, M. M. and Stracca, L. (2012). Getting beyond carry trade: What makes a safe haven currency? Journal of International Economics, 87(1):50-64.

Hamori, S. and Hamori, N. (2010). Introduction of the euro and the monetary policy of the European Central Bank. World Scientific.

Hau, H. and Rey, H. (2004). Can portfolio rebalancing explain the dynamics of equity returns, equity flows, and exchange rates? American Economic Review, 94(2):126-133.

Herger, N. (2016). Panel Data Models and the Uncovered Interest Parity Condition: The Role of Two-Way Unobserved Components. International Journal of Finance \& Economics, 21(3):294-310.

Im, K. S., Pesaran, M. H., and Shin, Y. (2003). Testing for unit roots in heterogeneous panels. Journal of econometrics, 115(1):53-74.

IMF (2017). Annual Report on Exchange Arrangements and Exchange Restrictions 2017. Technical report, International Monetary Fund.

Inoue, A. and Rossi, B. (2019). The effects of conventional and unconventional monetary policy on exchange rates. Journal of International Economics, 118:419-447.

Jammazi, R., Ferrer, R., Jareño, F., and Hammoudeh, S. M. (2017). Main driving factors of the interest rate-stock market Granger causality. International Review of Financial Analysis, 52:260-280.

Joyce, M., Miles, D., Scott, A., and Vayanos, D. (2012). Quantitative easing and unconventional monetary policy-an introduction. The Economic Journal, 122(564):F271F288.

Kenourgios, D., Drakonaki, E., and Dimitriou, D. (2019). ECB's unconventional monetary policy and cross-financial-market correlation dynamics. The North American Journal of Economics and Finance, 50:101045.

Kool, C. J. and Thornton, D. L. (2012). How effective is Central Bank Forward Guidance. Technical report, Federal Reserve Bank of St. Louis, Working Paper N. 2012-063A.

Krugman, P. (2014). Currency regimes, capital flows, and crises. IMF Economic Review, 62(4):470-493.

Kucharčuková, O. B., Claeys, P., and Vašiček, B. (2016). Spillover of the ECB's monetary policy outside the euro area: How different is conventional from unconventional policy? Journal of Policy Modeling, 38(2):199-225.

Mishkin, F. S. (2001). The transmission mechanism and the role of asset prices in monetary policy (No. w8617). Technical report, National bureau of economic research. 
Neely, C. J. (2015). Unconventional monetary policy had large international effects. Journal of Banking \& Finance, 52:101-111.

Pesaran, M. H. (2007). A simple panel unit root test in the presence of cross-section dependence. Journal of Applied Econometrics, 22(2):265-312.

Plümper, T. and Troeger, V. E. (2008). Fear of floating and the external effects of currency unions. American Journal of Political Science, 32(3):656-676.

Ranaldo, A. and Söderlind, P. (2010). Safe haven currencies. Review of Finance, 14(3):385-407.

Raskin, M. (2013). The Effects of the Federal Reserve's Date-Based Forward Guidance. Technical report, FEDS Working Paper No. 2013-37.

Rogers, J. H., Scotti, C., and Wright, J. H. (2018). Unconventional monetary policy and international risk premia. Journal of Money, Credit and Banking, 50(8):1827-1850.

Rybacki, J. P. (2019). Does Forward Guidance Matter in Small Open Economies? Examples from Europe. Econometric Research in Finance, 4(1):1-26.

Simáková, J. (2016). The Gravity Modelling of the Relationship between Exchange Rate Volatility and Foreign Trade in Visegrad Countries. Economic Studies 8 S Analyses/Acta VSFS, 10(1):7-31.

Stavarek, D. (2010). Exchange market pressure and de facto exchange rate regime in the euro-candidates. Romanian Journal of Economic Forecasting, 13(2):119-139.

Svensson, L. E. (2000). Open-economy inflation targeting. Journal of International Economics, 50(1):155-183.

Swanson, E. T. (2017). Measuring the effects of Federal Reserve forward guidance and asset purchases on financial markets (No. w23311). Technical report, National Bureau of Economic Research.

Taylor, J. B. (1993). Discretion versus policy rules in practice. In Carnegie-Rochester conference series on public policy, North-Holland, volume 39, pages 195-214. Elsevier.

Taylor, J. B. (2001). The role of the exchange rate in monetary-policy rules. American Economic Review, 91(2):263-267.

Thornton, D. L. et al. (2014). QE: is there a portfolio balance effect? Federal Reserve Bank of St. Louis Review, 96(1):55-72.

Van Bergeijk, P. A. and Brakman, S. (2010). The gravity model in international trade: Advances and applications. Cambridge University Press. 
Woodford, M. (2012). Inflation targeting and financial stability. Technical report, NBER Working Paper No.17967, National Bureau of Economic Research. 